
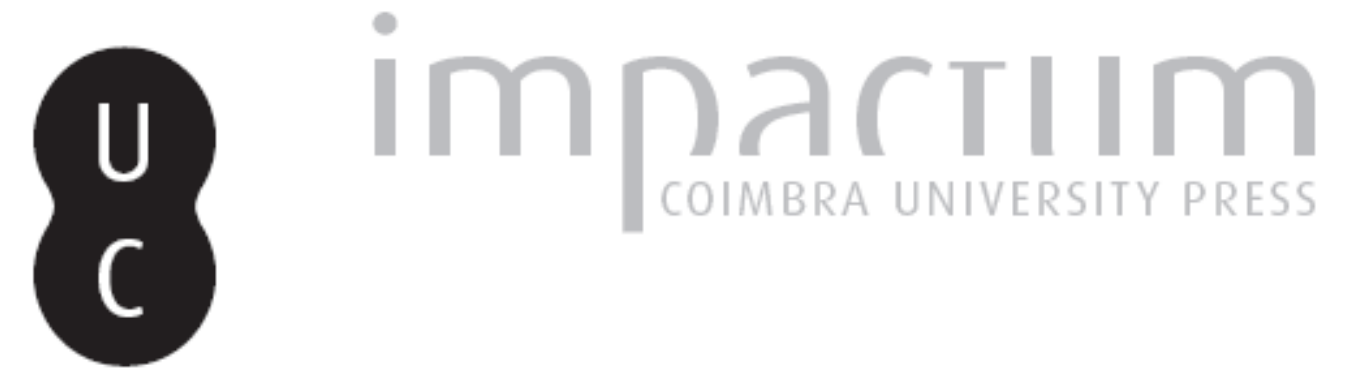

Uma análise reinterpretativa do sujeito passivo na participação de suicídio

Autor(es): $\quad$ Riski, Márcio

Publicado por: Universidade Católica de Petrópolis

URL persistente:

URI:http://hdl.handle.net/10316.2/33912

DOI:

DOI:http://dx.doi.org/10.14195/2175-0947_1-1_12

Accessed : $\quad$ 26-Apr-2023 15:48:40

A navegação consulta e descarregamento dos títulos inseridos nas Bibliotecas Digitais UC Digitalis, UC Pombalina e UC Impactum, pressupõem a aceitação plena e sem reservas dos Termos e Condições de Uso destas Bibliotecas Digitais, disponíveis em https://digitalis.uc.pt/pt-pt/termos.

Conforme exposto nos referidos Termos e Condições de Uso, o descarregamento de títulos de acesso restrito requer uma licença válida de autorização devendo o utilizador aceder ao(s) documento(s) a partir de um endereço de IP da instituição detentora da supramencionada licença.

Ao utilizador é apenas permitido o descarregamento para uso pessoal, pelo que o emprego do(s) título(s) descarregado(s) para outro fim, designadamente comercial, carece de autorização do respetivo autor ou editor da obra.

Na medida em que todas as obras da UC Digitalis se encontram protegidas pelo Código do Direito de Autor e Direitos Conexos e demais legislação aplicável, toda a cópia, parcial ou total, deste documento, nos casos em que é legalmente admitida, deverá conter ou fazer-se acompanhar por este aviso.

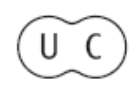



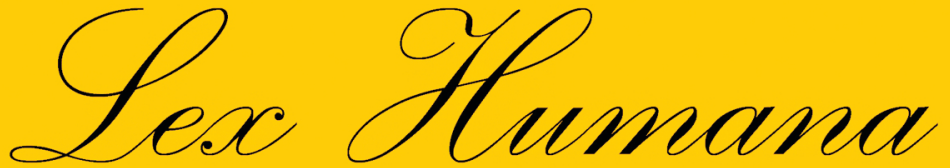

Revista do Programa de Pós-Graduação em Direito da UCP

ISSN(e) 2175-0947

Universidade Católica de Petrópolis Rua Benjamin Constant, 213 - Petrópolis - Centro CEP 25610-130

Tel: (24) 2244-4000 E-mail: lexhumana@ucp.br 


\section{UMA ANÁLISE REINTERPRETATIVA DO SUJEITO PASSIVO NA PARTICIPAÇÃO DE SUICÍDIO-}

Márcio Riski

\section{Prólogo}

Não raras as práticas estatais propagadoras do autocídio $^{1}$ e, curiosamente, espalhadas pelas mais diferentes culturas do globo. Este artigo não se propõe, primacialmente, analisar os fatores ${ }^{2}$ sociais ensejadores deste tipo de conduta; ao contrário, utiliza-os tão somente para demonstrar que certos bens jurídicos - dentre os quais a vida assume o ápice das condições existenciais - têm seu valor relativizado em culturas variáveis.

Também nessa ordem de idéias, devemos concentrar o alcance das normas penais incriminadoras da propagação do suicídio e não das práticas suicidas, propriamente ditas. Ao contrário das culturas ocidentais, percebemos sua apologia propagada exatamente pelos responsáveis na imposição da pena, ou melhor, pelo próprio Estado. Citamos, a título de

$1 \quad$ O vocábulo suicídio advém do latim sui, significando de si, que somado ao sufixo caedere - matar - gera o entendimento do ato praticado com o intuito de dar morte a si próprio. Alguns estudiosos procuram definir o suicídio como um ato pelo qual o indivíduo procura voluntariamente a morte e, levando-se em conta que tal prática, segundo a experiência, tenha sua reiteração em culturas absolutamente distintas, na mesma proporção observa-se a variação das causas que levam a sua execução.

2 Segundo os estudiosos, os motivos aparentemente comuns na prática do autocídio são a culpa, a vergonha, auto-acusação, o ressentimento, a vingança etc. Aqui citam os autores os fatores peculiares, pois há povos adoradores dessa conduta em decorrência de estímulos meramente espirituais, como ocorre na maioria das culturas orientais. Nestes casos, aqueles que a apreciam não avaliam a morte como uma pena aflitiva, e sim como um grande galardão para ao plano metafísico. 
ilustração, a moral islâmica ${ }^{3}$, a cultura bélica japonesa ${ }^{4}$ representada pelos tão conhecidos Kamikazes ${ }^{5}$, sua execração pelo pensamento cristão ${ }^{6}$ e, 3 Islam, do árabe, "submissão à vontade divina", é o termo mulçumano ou muslim que tem como tradução aquele que se submete à verdadeira fé. Essa doutrina preconiza um monoté́smo rigoroso, surgido a partir do século VII na Arábia, em contraposição a um número extenso de comunidades pagãs com diversos deuses não personificados ou associados a plantas e árvores, muito embora houvesse várias tribos esparsas adeptas do Judaísmo e do Cristianismo. A origem da civilização islâmica dá-se através de Muhammad - latinizado para Maomé. Conhecido como o último apóstolo de Deus, Maomé lutou contra uma oligarquia mercantil exploradora dos pobres e oprimidos, localizada na cidade de Meca. Convertendo a maioria das tribos Árabes, impôs-lhes uma série de leis morais e civis, codificadas no livro sagrado do Alcorão, cujo sentido literal prometia aos bons e corajosos o paraíso. Os infiéis - assim chamados quando não seguem com rigor a palavra sagrada - sofrem sérias discriminações pelos adeptos fundamentalistas. Estes extremistas interpretam os ensinamentos com excesso de rigor literal e gramatical, afastando-se de seus aspectos teleológicos. Entre suas condutas radicais, estaria o incentivo ao suicídio em nome das sagradas escrituras. Trata-se de atitude extrema, mas que, segundo revelam os mais radicais, torna-se o meio mais heróico de se atingir o paraíso.

$4 \quad$ Ainda no século XII, dominavam no Japão os comandantes denominados sei - tai - xogum, termo que significava "generalíssimo para subjugação dos bárbaros". Deste originou-se o vocábulo xogum cuja função - conta a real história - era a implantação de um governo paralelo ao comando do imperador. Desse modo, o chefe do trono se mantinha no poder sem, no entanto, governar, favorecendo o poder central do xogumanto.

Um dos fatores que contribuiu para a centralização do poder foi a ameaça invasora dos mongóis, cujas tropas eram demasiadamente superiores às japonesas. Como, então, enfrentar a total desproporção bélica? Inesperada e misteriosamente, fenômenos naturais, como maremotos e tempestades, destruíram as tropas mongólicas, precisamente em batalhas consideradas decisivas.

$5 \quad$ As forças armadas nipônicas criaram, durante a segunda guerra mundial, os combatentes Kamikazes. Alertam os escritos para a origem do termo "kamikaze", cuja tradução literal apontaria para o significado "vento divino". tal denominação justificar-se-ia na homenagem aos pilotos suicidas, os quais, nos mesmos moldes das tempestades e furacões devastadores dos mongóis no século XII, surgiriam como última opção na consecução dos objetivos bélicos japoneses. 6 Segundo o Concílio de Arles, realizado no ano 452, o suicídio era inspiração diabólica. A própria religião judaica - pré-cristã - condenava o suicídio no Deuteronômio, quinto livro do Pentateuco. A propósito, um dos mandamentos da lei mosaica determinava ao servo de Deus o amor para com seu criador, como 
curiosamente, afastando qualquer fórmula de que tais práticas fossem oriundas da ignorância científica e de sua acepção racional, o pensamento grego $^{7}$. Ocupam essas linhas, portanto, da intelecção do leitor na constatação, regra geral, do envolvimento das forças estatais na instigação do suicídio, ainda que sua motivação ocorra por motivos patrióticos. Destarte, rompe-se com a imaginação de que tais medidas extremas sejam praticadas, em sua totalidade, influenciadas por dogmas religiosos.

Não seria absurdo descartar a conclusão tomada pelo ilustre mestre Paulo Lúcio Nogueira ${ }^{8}$, quando afirma estarem todas as concepções religiosas contrárias ao autocídio:

Como se vê, todas as religiões são contra o suicídio, por se tratar de crime contra a vida, que é dádiva de Deus e que só por Ele pode ser tirada. Mesmo nos sofrimentos mais atrozes a criatura recebe do seu criador forças necessárias para

para consigo mesmo.

Ainda na linha cristã, o codificador da doutrina espírita - Alan Kardec - salientava não haver pior crime do que o suicídio, devido à interrupção da evolução espiritual do indivíduo.

Distanciando-se da análise punitiva do mundo espiritual, e analisando as fontes formais de punição do Direito Canônico daquela época, depara-se com certas curiosidades jurídicas do cristianismo oficial, tais como, a proibição de se fornecer aos mortos suicidas sepulturas religiosas. Muitas dessas sanções prescindiam de sentenças declaratórias, uma vez comprovada a notoriedade do fato.

Modernamente, acreditamos não mais perdurar este tipo de castigo, mesmo porque os cemitérios foram transformados em propriedades privadas.

$7 \quad$ No cerne da filosofia grega, havia o grupo de pensadores contrários ao espírito otimista de que as coisas mudariam com o pensamento critico da época. Em uma civilização dominada por dogmas religiosos e ignorância cientifica, os adeptos da racionalidade deparavam-se com o ínfimo incentivo à cultura e às artes existentes em quase todos os setores sociais das comunidades ditas "civilizadas". Surge, então, a escola de pensadores pessimistas, corrompendo todo ideal ligado ao livre-arbítrio humano. Para os pensadores gregos dessa época o suicídio não deveria ser punido; ao contrário, era mérito para quem o aconselhasse, levando-se em conta que, seguindo a razão da época, para o homem, o melhor seria jamais ter nascido. 
enfrentar suas dores e vencer esses momentos de elevação e provação. A cada ser Deus saberá dar forças necessárias para superar as dificuldades. Aliás, Ele sabe o que podemos ou no suportar. Por isso, não se pode desanimar e, por pior que seja a crise, o homem não tem o direito de pôr fim à sua própria vida.

Sem a necessidade de se aprofundar no estudo dos costumes religiosos, facilmente percebe-se que muitas são as concepções fundamentalistas a incentivar o confisco da própria vida. Ademais, a conduta em questão era, da mesma forma, privilégio do pensamento laico, tal como demonstramos no pessimismo racional grego. Finalizando, não somente as ciências culturais do homem, mas também as ciências naturais apontavam - como bem frisou Charles Darwim em sua teoria evolucionista das espécies - suicídios em algumas sociedades de animais, forçando, por conseqüência, a aceitação do fenômeno como decorrência do equilíbrio natural.

Ultrapassada essa observação comportamental, forçoso concluir que, ao contrário do que pensavam os jusnaturalistas, os direitos fundamentais tais como a vida e a liberdade - consagrar-se-iam na medida de sua gradativa incorporação aos ordenamentos jurídicos dos Estados. Não obstante a aceitação dos direitos fundamentais como inspiração dos direitos naturais e do cristianismo, não se pode olvidar que os mesmos adeptos da corrente jusnaturalista já não mais impõem resistência a influência dos fatores reais ou históricos; ou como bem salienta o Professor José Afonso da Silva ${ }^{9}$ :

Não é uma nova observação correta essa de atribuir, ao surgimento de uma nova idéia de direito, tão profundamente revolucionária, inspiração de natureza basicamente ideal, sem levar em conta as condições históricas objetivas, que, na verdade, constituem a sua fundamentação primeira. As doutrinas e concepções filosóficas têm relevância enorme no processo. Mas elas próprias são condicionadas por aquelas condições

9 SILVA, José Afonso da, Curso de Direito Constitucional Positivo, 22 ${ }^{\mathrm{a}}$ edição, São Paulo, Malheiros Editores, 2002, p. 172. 
materiais. Surgem precisamente para ordena-las numa compreensão ideológica coerente [...].

Através da historicidade - característica inafastável das prerrogativas fundamentais do homem -, observa-se a redução da importância de certos bens jurídicos no sistema normativo de vários Estados, uma vez que tais direitos ainda não obtiveram, ao longo de sua evolução histórica, a imposição em seu sistema de normas. Suas próprias ordens jurídicas excluem a antijuridicidade do fato, supostamente criminoso, através de causas legais; ao revés, é a mesma ordem a incentivar o extermínio da vida em situações de ameaça ao status quo.

Desse modo, torna-se fácil concluir que o sistema de normas de determinada sociedade política é estabelecido segundo uma escala de importância dos bens jurídicos considerados relevantes para o Estado. Tomase a dimensão de cada um desses bens de acordo com os fatores ideológicos - subjetivos, portanto - influenciando, desse modo, o respectivo legislador, conciliados a elementos objetivos ou históricos, como já salientamos. Assim, por exemplo, um Estado, ao prescrever, em sua Carta Política, diversos preceitos e garantias democráticas, deverá promover a preferência pelos direitos fundamentais do homem em detrimento de interesses estatais mesquinhos e oligárquicos. Aliás, essa intelecção não conduz a uma concepção individualista frente ao Estado, mas sim, como bem frisou Pérez Luño 10 , "limitação imposta pela soberania popular aos poderes constituídos do Estado que dela dependem".

Insistindo nas linhas do respeitoso JoséAfonso da Silva ${ }^{11}$, concluímos pela necessidade de se conciliar os aspectos ideológicos, filiados à corrente jusnaturalista, com sua gradativa incorporação nas Cartas Políticas de cada Estado de origem democrática, revelando que "Ao situarmos sua fonte na soberania popular, estamos implicitamente definindo sua historicidade, que é precisamente o que lhes enriquece o conteúdo e os deve pôr em consonância com as relações econômicas e sociais de cada momento histórico".

É justamente por ter acolhido o agente do Poder Constituinte, em sua Carta Magna, a necessidade de se conciliar o Estado republicano brasileiro com os preceitos do regime democrático, que o órgão da função judicante

10 PÉREZ-LUÑO, Antônie Enrique. Los derechos humanos, significación, essatuto jurídico y sistema, Universidad de Sevilla, 1979, pp. 23 e 24.

11 Op. cit. p. 179. 
deverá fornecer aos dispositivos infraconstitucionais a maior extensão possível a fim de efetivar os direitos fundamentais, sempre compreendidos em sua acepção social. Com inteira razão, portanto, Mauro Capelletti ${ }^{12}$ quando afirma "que o Estado só atingirá o ápice democrático quando o Judiciário puder dar a efetividade social aos direitos fundamentais". É que, para o citado autor, os direitos fundamentais são perfeitamente declaráveis; árdua, no entanto, seria a tarefa em sua concretização.

É nessa ordem de idéias, de real procura na efetivação dos direitos fundamentais do indivíduo frente ao Estado, num constante embate para lograr a paridade de armas, é que buscaremos interpretar a norma penal incriminadora em tela. A priori, devemos, contudo, salientar que o lúcido regime democrático prevê não só a realização das vontades majoritárias, mas, antes de tudo, a conciliação dos princípios gerais do direito com o fator decisivo da soberania popular. Melhor explicando, não podemos entender democracia como a desenfreada realização da maioria apenas do ponto de vista aritmético; à frente dessa retrógrada posição, poderíamos, sem medo, afirmar que não haverá democracia sem a tutela também dos direitos das minorias, além da preservação e realização da ordem jurídica legitimada na vontade de ambos.

E é, enfatizando essa compreensão sobre os direitos fundamentais do homem, que pretendemos reinterpretar a norma penal em questão, lembrando sempre dois princípios de hermenêutica Constitucional: o da taxatividade da norma constitucional e o da presunção de constitucionalidade das normas infraconstitucionais. O primeiro dispõe que a regra da constituição deve ser sempre interpretada, limitando-se o âmbito de incidência ao explicito desejo do legislador constituinte. $\mathrm{O}$ segundo diz respeito à presunção relativa de que toda norma infraconstitucional ingressa na ordem jurídica com a qualidade de ser, presumidamente, compatível com a Constituição.

Ora, se toda lei ordinária nasce com presunção de constitucionalidade (segundo princípio acima relacionado), presume-se também que o legislador comum observe, constantemente, a vontade do constituinte originário, antes de promulgar qualquer ato legislativo, caso contrário, deveria ser expurgada do sistema normativo pelos mecanismos de controle de constitucionalidade. Da mesma forma em que a norma constitucional deva ser interpretada nos limites da vontade do legislador constituinte originário (primeiro princípio),

12 CAPPELLETTI, Mauro; GARTH, Bryant. Acesso à justiça. Trad. de Ellen Gracie Northfleet. Porto Alegre: Fabris, 1988, p. 31. 
mais ainda exige-se que a regra infraconstitucional seja compreendida de acordo com aquela mesma vontade. Caso contrário, deparar-nos-íamos com um verdadeiro paradoxo. Por essa ótica, nota-se ser imprescindível atentar para a Carta Política, para, só então, extrair julgamento de mérito de uma norma ordinária de conteúdo incriminador.

Do mesmo modo, qualquer norma infraconstitucional em exame deve possuir coerência geral com o sistema punitivo de normas, sob pena, por exemplo, de se ter que condenar o agente criminoso, ao mesmo tempo em que fosse imprescindível isentá-lo da mesma condenação.

Iniciamos, para tanto, com a seguinte indagação: qual o alcance do termo "alguém" prescrito no caput do artigo 122 do Código Penal?

2. Em busca da extensão do tipo penal e harmonização do sistema punitivo de normas

Observemos o que dispõe o caput do artigo 122 do Código Penal pátrio: "induzir ou instigar alguém a suicidar-se ou prestar auxílio para que o faça".

Antes de expressar qualquer juízo de mérito, atente-se para as palavras de Fernando de Almeida Pedroso ao citar o Ministro Ari Franco:

A esse respeito, diz muito bem o Ministro Ari Franco que o induzimento ou a instigação devem ser feitos a determinada pessoa, pois o preceito legal emprega o termo alguém, não bastando, pois, induzimento ou instigação de caráter geral, chamada pelos tratadistas de sugestão literária de suicídio. Inexiste, por conseguinte, ação de induzir ou instigar in incertam personam.

Com a máxima vênia, discordamos da posição pacífica da doutrina, quando se posiciona nitidamente de forma tecnicista e literal, olvidando uma reflexão mais apurada. A despeito daquilo que consideramos mais próximo dos ideais de justiça, os ilustres penalistas priorizam, no caso em tela, outro critério de hermenêutica jurídica, o qual, acreditamos, não estar amoldado aos postulados do Estado Democrático e, portanto, à vontade do Titular do Poder Constituinte. Não há duvida de que a nossa ilação não é constatada na opinião do ilustre magistrado quando reduz o termo "alguém" a pessoa 
determinada, filiando-se, por isso, a um critério de interpretação, segundo o resultado que visa obter, declarativa.

Não significa que devamos rechaçar, em todas as hipóteses, essa espécie de revelação normativa. Ao contrário do que imaginam os falsos interpretes, uma vez obscurecidos por preconceitos doutrinários, a interpretação declarativa faz-se necessária em vários tipos penais explicativos e incriminadores, sob pena de se imputar ao magistrado conduta abusiva em seu poder interpretativo. Observa-se, por exemplo, o artigo 141, III, do Código Penal brasileiro, ao se referir a uma causa especial de aumento de pena por ter o agente ofendido a honra de alguém na presença de "várias" pessoas. Extraindo o real sentido da regra citada, não árduo concluir que sua norma revela se tratar de mais de duas pessoas, não importando fixar uma quantidade precisa delas. Caso o legislador desejasse referir-se a, por exemplo, apenas três ouvintes, teria de fazê-lo expressamente, evitando com isso arbitrariedades de julgamento.

Todavia, a interpretação de natureza precisamente declaratória merece alguns cuidados ou, intempestivamente, os falsos reveladores da norma a utilizariam como instrumento de vingança. Na causa majorante referente ao delito de injuria, buscou-se obter um resultado que pudesse evitar um excesso de interpretação, levando-se em conta que tal critério conduziria a um resultado injusto. Caso, a título de ilustração, estivessem presentes apenas três testemunhas quando da prática da ofensa, e se utilizasse o julgador de uma interpretação ampliativa (entendendo, por exemplo, que "várias" revela o sentido de quatro indivíduos ou mais), estaria o magistrado decidindo além de sua discricionariedade. Logo, desatenderia a um dos fins dessa norma jurídica, qual seja, a de aumentar a punição do delinqüente, considerando que a vítima teve sua dignidade aviltada na presença de três observadores. Por que razão majorar a pena se estivessem presentes cinco testemunhas e não apenas quatro?

Fez-se, em face desse raciocínio, a opção por dois critérios de hermenêutica visando a justa entrega da prestação jurisdicional. O primeiro deles revela o melhor caminho na obtenção de nossos anseios diante do caso concreto: a interpretação literal; o segundo nada mais é do que desdobramento do primeiro, buscando, com isso, extrair-se da interpretação declarativa o melhor resultado na revelação da vontade da lei, não estendendo ou restringindo o sentido da regra majorante.

Pelo exposto, qual seria o melhor método de interpretação objetivando extrair o melhor sentido para termo "alguém", previsto no art. 122, caput, do 
Código Penal? A posição pacífica, sabe-se, é a de que não se pode conceber o vocábulo em questão fora de seu conteúdo literal. Com efeito, forma-se a intelecção de que somente pessoa determinada seria vítima da participação do suicídio, vedando-se as induções de caráter geral. Trata-se de isentar de pena os autores de obras literárias famosas, segundo palavras do saudoso Mestre Mirabete ${ }^{13}$ :

É indispensável para a ocorrência do crime em estudo que a vitima seja pessoa determinada. A conduta deve ter como destinatário uma ou várias pessoas certas, não ocorrendo o ilícito quando se trata de induções ou instigações de caráter geral e indeterminado. Não há crime quando, por exemplo, um autor de obra literária leva leitores ao suicídio, pela influencia das idéias de suas personagens, como ocorreu após a publicação de Werther, de GOETHE, e René, de CHATEAUBRIAND. Na mesma situação encontra-se recente obra em que se expõem os vários métodos para a eliminação da própria vida.

Fernando de Almeida Pedroso ${ }^{14}$ compartilha do mesmo pensamento, aliás, como o faz a totalidade da doutrina a respeito do tema em questão: "As ações incriminadas em tela, por conseguinte, devem endereçar-se a pessoa determinada, ou a um grupo determinável de pessoas".

O método interpretativo acima, parece, a priori, incontestável, uma vez que busca excluir do pólo passivo da infração indivíduo ou grupo indeterminado. A justificativa dos autores estaria, a priori, no tipo subjetivo, ou melhor, na vontade direta de induzir, instigar ou auxiliar pessoa ou grupo certo ao cometimento de suicídio, sendo o resultado "morte" mero elemento subjetivo do próprio tipo. Assim, a vontade do autor estaria tão-somente na indução, instigação ou auxilio, e não no confisco da vida, elemento secundário na caracterização dessa infração. Propõe-se, com efeito, o sujeito

13 MIRABETE, Júlio Frabini. Manual de Direito Penal. Atlas, São Paulo, 1991, Vol. 2, p. 62.

14 PEDROSO, Fernando de Almeida. Dos Crimes Contra a Vida. Aide, 1996, p. 204. 
ativo a induzir determinada pessoa ou coletividade, ainda que não se logre o objetivo final mais gravoso. Embora não seja este o objeto central de nosso debate, não podemos aceitar tal raciocínio. Quando alguém demonstra o desejo de participar da autoquiria, traz, ínsito em sua conduta, o pensamento de produzir o resultado morte. Outra conclusão não se pode extrair.

Por via de conseqüência, não se conceberia a idéia de estar o autor do delito responsável pelos resultados produzidos in incertam personam, uma vez tendo desejado atingir alguém de forma voluntária e espontânea. Observa-se, portanto, ser inoportuna a discussão sobre a existência ou não da morte como dolo especifico.

A despeito do que se demonstra pacificado, é-nos permitido, embora sem a pretensão de rechaçar o pensamento unânime de consagrados juristas, ao menos, alertar para certa incongruência normativa, acreditamos, nunca antes alertada. O que se propõe neste trabalho é a demonstração de serem descabidos, na melhor reflexão sobre quem possa ser o sujeito passivo na participação de suicídio, os métodos interpretativos literal e declarativo. Acreditamos não estarem filiados tais critérios, diante da análise especifica dessa infração, aos ideais de justiça. Passamos a justificar, neste momento, nossa inconformidade.

Insistir no critério já assentado, puramente literal de revelação do sentido da norma, contribuiria por produzir não apenas a incoerência dessa regra diante do conjunto normativo penal, mas também a desproporção entre a fruição das liberdades individuais constitucionais. Senão vejamos: qual seria o crime praticado pelos criadores de obras propagadoras do autocídio? Após o uso da intelecção estritamente gramatical, responderíamos: nenhum, pois a conduta em questão não se amolda a descrição de qualquer figura típica na lei penal incriminadora. Ao leitor estaria dada a permissão de rebater nossa pretensão indagando: não configuraria tal ação apologia de crime, levandose em conta que o autor agiu publicamente, tal como se afigura no art. 287 do Código Penal brasileiro? Responderíamos negativamente, uma vez que o suicídio, de per si, não é tipificado na lei penal. Como responsabilizar o autor por propagar um fato, o qual, ontologicamente, sequer constitui infração delituosa? Ora, se excluirmos a hipótese de enquadrar a referida conduta no tipo "participação em suicídio", e se, do mesmo modo, incluíssemos sua inserção no tipo "apologia de crime", concluiríamos pela atipicidade do ato. Quanto a essa constatação não haveria qualquer absurdo, uma vez que nem todo fato ilícito é, inexoravelmente, criminoso.

Tal assertiva não acarretaria, de nossa parte, qualquer insurgência, 
não fossem as conseqüências paradoxais geradas pela doutrina dominante. A sugerida contradição estaria, acreditamos, na irreflexão ou, pelo menos, na necessidade premente de se proteger, a todo custo, a liberdade individual de expressão.

Quando os ilustres autores priorizaram os métodos literal e declarativo geraram a absurda situação de punir o responsável pela morte de uma ou de poucas pessoas determinadas, isentando de culpa, em contrapartida, aqueles que apregoaram a morte de muitos, embora indeterminados. Ademais, é notório o fato de que, quando se atua assumindo o risco de produzir determinado resultado, não se indaga quais ou quantas pessoas imaginava-se atingir. Basta observarmos o exemplo do motorista relapso. Este, embora confiante de suas habilidades, ainda assim não se importa com a deflagração final do evento. O referido resultado, embora previsto quanto ao tipo de lesão, pode estender-se a uma, poucas ou várias pessoas, em escala não invariável, porquanto imprevisível quanto ao número de lesados.

Buscando a coerência deste raciocínio, basta que se relembre o art. 121 do CP, quando sanciona, com pena de reclusão, o agente disposto a matar "alguém". Em nenhum momento a doutrina quis excluir da interpretação do termo em destaque um número indeterminado de pessoas. Basta imaginarmos a conduta de um terrorista decidido a fazer implodir uma bomba-relógio em praça pública. Não poderíamos afirmar que sua ação estivesse dirigida a certas pessoas ou, pelo menos, a um grupo determinável delas, uma vez que o número de vítimas produz-se através de uma margem de variação indefinida.

Caberia, diante da ilustração, concluir pela absurda hipótese da não imputação do agente terrorista pelas várias mortes, apenas pelo fato de que o tipo penal do homicídio faz alusão ao vocábulo "alguém”? Absolutamente. Seria como se permitir o homicídio simples e tornar impunível o homicídio qualificado. A propósito, o próprio $\mathrm{CP}$ refere-se à qualificadora do homicídio em situação que possa causar perigo comum (art. 121, $\S 2^{\circ}$, III, in fine). Ora, se a lei incrimina o perigo comum (circunstância menos grave) - sabendo-se que o termo "comum" não se vincula a um número determinável de pessoas -, não iria incriminar o próprio assassinato de indeterminada quantidade de indivíduos? Por que razão, então, não nos seria permitido usar do mesmo critério na interpretação do sujeito passivo no crime previsto no art. 122? Ademais, não prevê a lei penal a majoração da punição para casos em que uma única ação é cometida com resultados lesivos vários? Diante do que restou patente, seria o agente responsável pelo molestamento capaz de direcionar sua conduta a um ou vários indivíduos previamente determinados? 
Embora não se possa apontar, categoricamente, a incoerência da doutrina na utilização de critérios distintos na busca pela definição do sujeito passivo nos tipos "participação em suicídio" e "homicídio", pode-se afirmar, sem temor, que a doutrina estabeleceu critérios desiguais quanto à punição de fatos lesivos da mesma gravidade. Basta que se observe, conforme descrevemos, a absoluta atipicidade do fato para aqueles que propagam, genericamente, o autocídio. Aliás, o próprio legislador tem demonstrado sua incoerência ao punir a tentativa do indutor apenas quando, não obtida a morte, o induzido sofrer lesões corporais graves.

Quando se busca utilizar a interpretação extensiva ou restritiva, demonstra-se a insatisfação entre o resultado da interpretação lógica e o da gramatical, ampliando ou encurtando o seu sentido final. Se até mesmo a exegese demonstrou-se insatisfeita com a revelação literal do vocábulo "alguém" no tipo homicídio, estendendo seu alcance para além das vítimas determináveis (quando se refere ao perigo comum), não seria sensato usar do mesmo critério para as vítimas da indução ou instigação do autocídio? Mesmo não desejando diretamente a morte de várias pessoas, não estaria assumindo o risco de produzir mais de um evento lesivo, ainda que a um grupo de quantidade indeterminável delas?

Acrescentamos a essas linhas o não-esquecimento da mesma Lei Penal, positivando punição para resultados obtidos pelo concurso formal. Recordemos o exemplo do terrorista ao detonar uma bomba na entrada de um prédio militar. Mesmo desejando confiscar a vida de militares em quantidade determinável, não estaria se importando com a morte de quantidade indeterminável de civis que ali transitavam. Utilizar-se-ia o mesmo raciocínio para aquela hipótese de um eletricista experiente que não fizesse os reparos necessários na fiação elétrica de um prédio público. Mesmo acreditando na razoável probabilidade de ocorrência de um incêndio, o citado profissional não conduz seus atos na prevenção do acidente. Não esperava sinceramente que tal infortúnio não ocorresse, porquanto imaginou ser muito provável o resultado fatal. Pelo exposto, deixaria o meliante de responder, em concurso formal, pelas mortes inesperadas, embora não desejadas diretamente? Haveria, neste último exemplo, a expectativa de se atingir pessoas determinadas ou determináveis? Parece cristalina uma resposta negativa. Caso pudéssemos apontar uma quantidade determinável, por que, então, não o faríamos com relação às vítimas das citadas obras literárias?

Poder-se-ia questionar nossa discordância, sob a argumentação 
de que a lei previu, para o tipo penal "homicídio", a necessidade de se demonstrar a direta intenção em matar pessoa certa ou várias delas em quantidade determinável. O mesmo raciocínio não seria coadunável com os autores de obras literárias de incentivo ao suicídio, devido à não realização de qualquer ato executivo capaz de produzir o evento morte. Tudo porque os livros de Goethe e Chateaubriand seriam mera demonstração da liberdade artística e científica, não se cogitando, especificamente em números precisos, da expectativa gerada pelo alcance de suas linhas, uma vez que nem todos estariam forçados à aquisição de seu conteúdo. Desse modo, diversamente do que ocorre como homicídio, cujas vítimas, mesmo indeterminadas, não podem escolher pela sobrevivência, a influência para o cometimento do autocídio sugere opção pela discordância do conteúdo das obras mencionadas. O leitor teria a opção, portanto, de reagir às pressões fantasiosas de um autor literário, separando a ficção da realidade, preferindo a vida - decorrência do extinto natural - à morte.

Data vênia, torna-se prudente, mais uma vez, discordar. Analisando o tipo objetivo do art. 122, observam-se os verbos induzir e instigar, mesmo antes da colaboração material com o suicida, traduzida essa na forma de auxílio. Como já enfatizado, o dolo é a vontade direta em induzir, instigar, além de, materialmente, colaborar para sua realização e não, necessariamente, conseguir o resultado morte, embora essa esteja ínsita no tipo subjetivo. De fato, as vítimas de homicídio com dolo eventual têm resistência quase nula diante do fato absolutamente inesperado, o mesmo não sucedendo com a participação em suicídio. No entanto, justamente por ser o homicídio fato mais gravoso em suas conseqüências, é que o legislador estabeleceu, na mesma proporção, sanções mais graves. Da mesma forma, não questionamos o enquadramento dos autores literários no delito de homicídio, mas sim na participação de suicídio.

Outros poderiam edificar críticas à nossa posição, acusando-a de utilização de analogia em prejuízo do acusado. Recusamos, do mesmo modo, tal argumento, pelo simples motivo de não acolhermos, entre os nossos propósitos, a integração de norma mais grave (homicídio) na norma de maior brandura (participação em suicídio). Mesmo porque, em nenhum momento, questionamos a quantidade dessa pena. A reivindicação vinculase a não-extensão do termo "alguém" - contido no preceito primário dessa norma - àqueles excluídos insistentemente pela doutrina. Rejeitase, igualmente, o pensamento de que seria inviável o uso da interpretação extensiva em prejuízo do acusado, restrição imposta apenas à analogia, 
espécie de integração normativa. Como bem salientou o saudoso Hermes Lima $^{15}$, a interpretação extensiva

[...] corrige a má expressão ou redação que, embora procurando estabelecer regra geral, diminui-lhe a extensão do pensamento, como, no caso da designação da espécie por gênero. Reintegradora do pensamento legislativo, a interpretação extensiva, adverte Ferrara, aplica-se a todas as normas, mesmo às de caráter excepcional ou penal.

Nosso objetivo volta-se para a permuta do critério interpretativo, e não para, contrariando os preceitos constitucionais democráticos, o beneficio do método integrativo-analógico in malem partem. Todavia, não se deve conceber, aleatoriamente, a ampliação do termo estampado na regra. Justificar-se-ia este artifício sempre que o resultado extraído do critério puramente declarativo demonstrasse incoerência com os resultados obtidos pela interpretação de outras regras dotadas de características semelhantes. Desse modo, por que, em caso de homicídio, responsabilizar seu autor por quantidade indeterminada de mortes, uma vez que agiu com dolo eventual, e não fazê-lo com relação à participação em suicídio, tendo este tipo subjetivo se caracterizado da mesma forma?

Consideramos não convincente $\mathrm{o}$ atual pensamento doutrinário, pelo motivo de vincular-se a um critério puramente literal-declarativo. Como demonstramos, essa ilação excluiria, de modo incompreensível, eventuais vítimas do incentivo a autoquiria, pela simples razão de não constituírem o fito preliminar do suposto agente delituoso. Não nos pareceu convincente tal raciocínio, bastando recordar as várias hipóteses de homicídios praticados com dolo eventual em concurso formal. Nessas situações, o responsável pelas mortes agiu segundo um contexto de previsibilidade, tendo também previsto o evento lesivo, mas que, embora confiando em suas habilidades, demonstrou-se indiferente para as conseqüências irremediáveis de sua conduta. A tese de que o responsável pelo dolo eventual, embora não querendo diretamente o resultado, pudesse prever quais ou quantas pessoas poderia alvejar, entre nós, não encontra respaldo. E insistimos: no exemplo 
citado, embora o sujeito ativo possa prever, numa escala de variação precisa, quais os eventos possíveis a se concretizarem (mortes, lesões, danos), o mesmo não se permitiria afirmar do número de destinatários de sua conduta. Isso se justificaria por ser inviável sua estimação dentro de uma escala de limites mínimos e máximos. Quantas seriam as vítimas de um atentado terrorista, mil, mil e quinhentas, duas mil e duzentas? Ainda assim, nega-se a aplicação da regra do art. 121 do $\mathrm{CP}$, cujo tipo descreve a conduta "matar alguém"? Obviamente que não. Por que, então, não utiliza a doutrina do mesmo critério para os autores de obras literárias? Não seria facilmente cognoscível o resultado morte, não obstante imprevisível, dentro de uma escala de variação precisa, o número de atingidos?

Em verdade, o principal motivo pela ampliação ou restrição do conteúdo de um texto normativo está na necessidade precípua de se harmonizar as normas de um sistema. Seria, desse modo, defeso ao intérprete revelar o conteúdo de norma específica sem atentar para o contexto em que se insere, sob pena de tornar incoerente a aplicação das demais normas. Há, o que se observa em doutrina, uma certa disparidade entre o mens legis e o verba legis, podendo o jurista aumentar o alcance do dispositivo ou contraílo. Como exemplo, embora distante da esfera criminal, podemos citar o art. 175 da Constituição de 1967, a qual afirmava ser o casamento indissolúvel, quando o próprio sistema normativo autorizava a dissolução do matrimônio - e isso ocorreria inexoravelmente - com a morte. Foi preciso, então, que se restringisse o alcance da norma para não tornar, de um lado, indissolúvel o matrimônio e, de outro, permitir sua anulação ou sua extinção. $\mathrm{Na}$ realidade, não se pode afirmar, diante desse exemplo, ter havido contradição de intenções por parte do legislador originário. Firmou-se, por isso, a determinação de uma regra geral visando a proteção do casamento contra as hipóteses arbitrárias contidas em pactos antenupciais e, por conseqüência, não recepcionáveis pela Carta Política, sem que, para tanto, excluísse as exceções enquadradas nessas exigências.

Há, ao revés, a necessidade de se ampliar o alcance do termo empregado na regra, evitando, com efeito, paradoxos jurídicos, tais como punir por fato menos grave e não puni-lo por conduta mais gravosa. Observase, para tanto, o delito de bigamia, o qual, por mera revelação lógica, atinge não somente aquele que contraiu o segundo matrimônio, mas também o que permitiu celebrar vários casamentos. Assim como salientou Mirabete ${ }^{16}$, 
"Deve-se concluir, por exemplo, que o artigo 235 se refere não só à bigamia, como também à poligamia".

Seguindo a mesma ordem de idéias, podemos cogitar da necessidade de estendermos o sentido do termo "alguém", previsto no tipo do artigo 122, para além de sua acepção literal ou gramatical. Evitar-se-ia, com efeito, a incoerência do sistema punitivo de normas, uma vez que em outros preceitos primários não se exclui a punição do agente criminoso pela lesão a um número indeterminável de vítimas. O que é plausível - e sobre isso não há questionamentos - é a previsibilidade sobre quais bens jurídicos são passíveis de molestamento. Mesmo tendo agido com vontade direta e contra vítimas determinadas (ou determináveis), extrai-se da própria inteligência do conjunto normativo a exigência de não se permitir impunidades quando o bem jurídico for diverso daquele que se pretendia atingir. Destarte, observase o mesmo Código Penal em seus artigos 73 e 74. O primeiro (erro na execução) busca incriminar o agente que, mesmo por erro ou acidente, atinge pessoa diversa que pretendia ofender. Tal dispositivo veda a impunidade do autor do fato, uma vez que, em conjugação com o art. $20, \S 3^{\circ}$, proíbe a isenção de pena do "erro quanto à pessoa", mesmo levando em conta as qualidades de quem se desejasse atingir. No segundo (resultado diverso do pretendido), apesar de referir-se à punição apenas na forma culposa, demonstra o legislador o desejo de não tornar qualquer fato impunível, a não ser no caso de imprevisão legal. Denota-se a preocupação da parte geral na criação de princípios aplicáveis à parte especial e, com efeito, não tornar impune fato previsível, ainda que oriundo de erro ou acidente.

Poder-se-ia afirmar que, em ambos os casos, se a vontade do autor não estivesse dirigida a pessoa(s) determinada(s), pelo menos previsível seria a ofensa vítima ou grupo determinável. Destarte, seguindo essa intelecção, não se pode estender o número de ofendidos para além daquilo que permitem as circunstâncias existentes no caso concreto. Quem atira, por exemplo, contra determinado indivíduo visando matá-lo no meio de multidão, assume o risco de ferir ou confiscar a vida de outras pessoas em valor apreciável; ou melhor, somente aqueles transeuntes podiam enquadrar-se na esfera de previsibilidade do autor (donde valor determinável).

Todavia, é-nos permitido relembrar uma ou outra situação em que a previsibilidade quanto a um número determinável de atingidos torna-se impotente. Imaginemos a premeditação (dolo direto) de homicídio contra determinada pessoa através de transmissão de doença infecto-contagiosa, mas que só produziria resultado letal após algum tempo. $\mathrm{Na}$ fase de 
instrução foi demonstrado que o autor, embora não desejando diretamente resultados letais, assumiu o risco de que tal contaminado pudesse transmitir, involuntariamente, a enfermidade aos habitantes de sua comunidade, previsão infelizmente concretizada. Por conseguinte, foi constatado que os moradores de regiões vizinhas e, posteriormente, de regiões mais afastadas já haviam sido atingidos pela moléstia. Diante do que foi descrito, questionase sobre qual crime a ser tipificado contra o transmissor principal da doença. Há quem diga homicídio em concurso formal com delito de epidemia (art. 267). Outros talvez afirmassem, com fundamento no dolo eventual, haver vários homicídios em concurso formal. Considerando que o autor conhecia o caráter letal de sua conduta, parece mais viável a conclusão de que sua vontade direta era a de matar e não a de propagar a epidemia. Ademais, o citado autor deve ser responsabilizado pelas mortes ulteriores, porquanto, além de se tratar de fato previsível e inexorável (a doença era letal), não se importou sinceramente em evitá-las.

Como está patente, acreditamos não vingar o pensamento de que o autor dirigia seu comportamento a vítimas certas ou determináveis, vez que tal análise escapa da invariabilidade quantitativa. Não podemos, desse modo, afirmar que sua conduta pudesse estar destinada a efeitos letais numericamente precisos, porquanto não há que se apontar quantos, mesmo na busca de dados prováveis ou termos percentuais, seriam os atingidos. Observa-se, portanto, enorme variação a não se permitir afirmar, dentro de uma escala aceitável, quantos seriam os sujeitos passivos.

Persistimos com o fulcro de nossa idéia e formulamos várias indagações, até o momento, não satisfatoriamente solucionadas: por que não estender o mesmo raciocínio para a responsabilização daqueles que instigam e induzem o suicídio em caráter geral? O artigo 122 do CP também não vincula a conduta do agente instigador ao termo "alguém"? Ao instigar ou induzir, não estaria o autor, embora não desejando diretamente o resultado, assumindo o risco de produzir diversas mortes? Na suposição de certos casos de homicídio, cujo bem juridicamente tutelado é a vida, fácil foi a ampliação do termo legal "alguém" para além das hipóteses de vítimas determinadas ou determináveis.

Nabusca pela simetria, não se pode olvidar-e isso tem se demonstrado notório - que os verbos previstos no artigo 122 contêm, de forma ínsita, a previsão da morte. Isso tanto se corrobora quando a própria doutrina entende só haver a punição - reclusão, de dois a seis anos - quando da ocorrência letal ou havendo, no mínimo, lesão corporal grave. Fez questão de salientar 
a doutrina que só o fato de instigar, induzir ou auxiliar não constituem, por si só, o delito em tela, bastando observar, para tanto, o preceito secundário da norma. Na observação dessa ilação, a priori, parecendo tratar-se de apenas mais uma minúcia, é que estaria um dos fundamentos de nossa posição. O propósito estabelecido pelo legislador de só incriminar o autor quando realizados os resultados morte ou lesão grave, já traz ínsita a idéia de fornecer a este tipo penal as mesmas características inerentes ao homicídio ou a sua tentativa. Um único elemento dá-lhe colorido especial, porquanto o participante depende de atitude positiva própria de sua vítima na execução do autocídio, embora acreditamos estar revestido da mesma roupagem do crime mais grave.

A peculiaridade do delito de participação em suicídio não constituiria, tão somente, fator capaz de isentar, em todos os casos, o autor de obras ou intelecções supostamente artísticas. Todavia, fazemos questão de atentar para a necessidade de se amoldar nosso posicionamento a cada caso concreto, rechaçando qualquer fórmula de conteúdo genérico. Tornar-se-ia meritória nossa idéia apenas quando estivessem alinhados todos os fatores necessários para a composição da infração. Enfim, não é de nosso alvitre a edificação de um embate contumaz a todo tipo de manifestação intelectual que, de forma imaginativa, pudesse estar promovendo a autoquiria.

Seguindo semelhante critério e buscando renegar fórmulas jurídicas de natureza condenatória (não é este o propósito deste artigo), faz-se mister uma atenta reflexão sobre os elementos que, uma vez coexistentes, fazem eclodir o delito. O que não nos afigura mais objeto de discussão é o fato de não se poder responsabilizar o autor pelo número indeterminável ou de variação indeterminada de vítimas. Essa, para nós, tornou-se posição inaceitável, diante do que restou patente na teoria do dolo eventual. Todavia, assim como repudiamos fórmulas incriminadoras, também o fazemos com relação a fórmulas descriminadoras.

Neste momento procura-se demonstrar que a simples exposição do pensamento a citar o suicídio como saída única para uma realidade irreversível, por si só, não é suficiente para a incriminação. Deve o intérprete, antes da adesão imediata a posições pacíficas ou meramente discordantes, refletir, com austeridade, sobre os elementos que compõem a conduta, tais como o subjetivo, objetivo e o normativo. A posteriori, deverá questionar, de modo inevitável, se tal conduta de expressão intelectual foi elemento diretamente responsável na consecução do suicídio, caso contrário haveria fato atípico.

No intuito de ampliar a compreensão do leitor quanto ao propósito 
de nossas linhas, citamos um caso, recentemente noticiado, sobre a suposta influência de novela televisiva intitulada "A Viagem" no cometimento de vários suicídios. A citada produção artística relatava, de forma fictícia, os problemas do cotidiano envolvendo um grupo de pessoas em sua relação de interdependência, buscando, em contrapartida, conciliá-las através dos mandamentos espíritas kardecistas. Em determinada fase da trama, certo personagem de um criminoso comete a autoquiria, uma vez não resistindo às mazelas do cárcere. Seguindo os princípios que norteiam a filosofia espírita, o responsável pelo confisco da própria vida deveria, após seu desencarne, continuar experimentando o sofrimento, agora mais intenso pela prática de um crime cujas conseqüências seriam, a priori, irremediáveis. Num segundo momento, demonstra a obra constituir o arrependimento meio para suprir qualquer ato errôneo, ainda que inicialmente incorrigível, na obtenção do perdão divino e, por conseguinte, seu envio ao paraíso.

Argumentando sob essa ótica final, parentes das vítimas clamaram pelo enquadramento dos autores da novela no tipo do art. 122, posição que merece absoluto desprezo de nossa parte. Como salientamos, não se trata de discordar da posição dominante buscando, a todo custo, responsabilizar qualquer manifestação intelectual cujo conteúdo esteja, direta ou indiretamente, relacionado ao suicídio. Considerando este relato, seria, no mínimo, espalhafatosa a conclusão de que o intelectual, neste caso, devesse ser punido; ao revés, a simples exposição na mídia das idéias já codificadas desde o século XVIII não é suficiente para o enquadramento do fato tipo penal em questão.

A alegação de que tal agente seria responsável pela suposta existência de previsibilidade do fato, sua previsão especifica e a aceitação do resultado mais grave, mesmo não o desejando diretamente, não seria aceitável diante da insuficiência dados na narrativa; isso porque não se constatou um lastro mínimo de provas que pudessem caracterizar o dolo eventual. Extrair conclusão que possa, irracionalmente, ensejar a condenação seria consagrar, em outros termos, a teoria de responsabilidade objetiva, adversativa ao Estado democrático brasileiro. Atente-se para o detalhe de que nossas idéias não têm respaldo neste tipo de imputação, porquanto nem sempre haveria, conforme salientamos, a responsabilização dos autores de obras artísticas ou intelectuais. A propósito, essa é a inteligência do art. 19 do Código Penal brasileiro, quando dispõe que "Pelo resultado que agrava especialmente a pena, só responde o agente que o houver causado ao menos culposamente".

No caso do exemplo citado, não se permitiu vislumbrar uma relação 
direta entre a manifestação intelectual do autor da arte e as mortes que, supostamente, dela teriam decorrido, porquanto não estaria ínsita na doutrina espírita qualquer propagação ao autocídio; muito pelo contrário, suas idéias condenam, de modo impetuoso, tal tipo de procedimento. Com o intuito de se elaborar tese contrária e, portanto, incriminadora, dever-se-ia certificar que a conduta do agente estivesse diretamente ligada ao propósito de, embora não demonstrando o desejo o resultado fatal, colaborar intensamente na sua consecução e, em face dela, não se importar com um resultado mais grave. Isto seria facilmente constatável, por exemplo, diante do apontamento de métodos ou substâncias indolores, do incentivo insensato ao pessimismo, da distorção de textos religiosos incentivando a revolta e as soluções ultraradicais etc.

Enfatizamos nosso desprezo pela edificação de uma teoria de imputação objetiva. Cremos que as ilustrações feitas, até aqui, em nada podem ser comparadas àquelas situações em que se tentou incriminar, por exemplo, o fabricante de armas de fogo, as quais, em perfeito estado, serviram para práticas de homicídio. Como se permite notar, nosso posicionamento alude a questões que de alcance mais extenso.

3. A Ótica do Critério Evolutivo: em busca da delimitação do sujeito passivo da incitação de obras literárias.

Advogando contra pacificado pensamento, alertamos para outro tipo de questionamento: até que ponto tais obras literárias não estariam voltadas na vulneração de pessoas certas ou um número determinável delas?

Buscando analisar o problema sob nova ótica, tratamos de, neste momento, anuir a posição da doutrina no estabelecimento de um sujeito passivo determinado ou determinável. O raciocínio de que as obras intelectuais não aspiram consumidores determinados ou em quantidade determinável, tornou-se efêmero diante dos fatos sociais que envolvem a indústria literária, agora muito mais voltada a questões mercadológicas do que propriamente artísticas ou científicas. Como já salientado, várias obras são redigidas em razão da estreiteza de seu objeto junto ao mercado de consumo. Dessa forma, não árdua é a evidência de que muitas delas já estão previamente destinadas a um público alvo, este, a cada dia, adquirindo maior grau de precisão. As liberdades negativas, notadamente, as de expressão intelectual, artística ou científica eram exercidas conforme o contexto histórico e social em que estivessem imersas. O marco histórico de sua conquista - período 
das Revoluções Liberais do século XVIII - propiciou o uso e o gozo dessas prerrogativas de acordo com uma realidade diversa da que possa entrever-se em dias atuais. Desse modo, as obras literárias, em tempos modernos, visam não mais atingir um público desmesurável. Fundamenta-se essa assertiva na evolução da estatística, o aperfeiçoamento das técnicas de publicidade e sua conciliação ao crescente acesso à informação do mundo globalizado.

É fato notório que, em tempos modernos, quase toda atividade artística vincula-se ao dever de corresponder às necessidades mercadológicas. De fato, o que se busca atingir numa sociedade altamente consumista, em nada está relacionado ao amor pelas artes ou pelo semelhante. Não se pode negar os altos investimentos dispensados por gravadoras e editoras na busca por vendagens espetaculares, sem que possa discutir, em tempo, a ausência dos seus componentes éticos. Considerando que tais atividades visam atingir um público alvo, ainda que este não seja o único, sempre se estará buscando um grupo determinado de indivíduos, não obstante não se possa mensurar aqueles ao qual pertencem.

Isso é por demais verídico, quando se atenta para o fato de que as próprias editoras encomendam pesquisas mercadológicas sobre a mensurabilidade dos leitores a serem alcançados. Um livro de auto-ajuda, por exemplo, tem sido, comumente, veículo de consumo de adolescentes. Outro sobre doenças cardíacas afetará uma classe, também em sua maioria, composta de fumantes e/ou obesos. Exceto no caso de obras literárias já absorvidas pelo patrimônio histórico-cultural, tal qual ocorre com a Bíblia, quase a totalidade delas envolvem um grupo determinado, ou, pelo menos, determinável de leitores. Imaginemos uma vítima de tentativa de homicídio e que, em decorrência de execrável conduta, tenha ficado tetraplégico. A partir deste panorama desalentador, decidiu contar em obra escrita seu suplício, indicando profunda depressão e vontade de aniquilar sua própria vida, além de apontar mecanismos na realização da autoquiria. Pergunta-se: embora não se possa apontar, com exatidão, quantos seriam os portadores dessa doença, não constituiriam os tetraplégicos, facilmente, um grupo determinável de pessoas? Cremos afirmativamente.

Pretendemos, pelo exposto, asseverar que o pensamento doutrinário dominante estaria vendo sua gradual relativização. Tal mudança deve-se à necessidade de readaptação da norma em face de nova realidade histórica. Aliás, eis aí o destino das técnicas de hermenêutica, qual seja, o de possibilitar que a vontade da regra - e não a do legislador - seja apreciada de acordo com o momento social que o inspira a disciplinar. Nesse contexto surge, 
aliado aos demais critérios de interpretação indispensáveis na discussão do presente tema, o elemento histórico. Como já salientado, não se compreende o conjunto de direitos fundamentais tão-somente na acepção do direito natural, tornando, por conseguinte, forçosa sua incorporação ao ordenamento jurídico de cada Estado.

Pois bem, sendo essa característica - historicidade - elemento fatal para a compreensão e a eficácia de um direito fundamental, forçosa também se tornou a revelação de seu sentido conforme a realidade histórica em que se insere. É, neste seguimento, que devemos buscar a atual compreensão do sujeito passivo na participação de suicídio. Nossa intenção, nessa parte do artigo, não é mais trabalhar com a hipótese de se permitir a incriminação do agente que tiver molestado vítimas em quantidade indeterminável, punindo-o pelo dolo eventual. A fim de submeter o pensamento doutrinário moderno a mais uma crítica, agora de natureza histórica, indaga-se o porquê de sua imutabilidade. Para a obtenção de solução convincente e, por conseqüência, permitir o afastamento da posição dominante é que, hipoteticamente, passase a aceitar a tese de que o sujeito passivo devesse ser vítima determinada ou grupo determinável. Mantém-se a apreciação da norma na busca pelo seu melhor resultado, porém, através de outra circunspeção. E seguindo essa nova perspectiva, deparar-nos-emos com a mesma necessidade de não se deixar impune o colaborador intelectual da autoquiria. Por este prisma, na adesão da communis opinio doctorum, filiou-se à interpretação declarativa como forma de não permitir a extensão do termo "alguém" para além das vítimas determinadas ou determináveis. Todavia, mesmo na manutenção deste método, faz-se necessária outra crítica, agora voltada ao fator premente de se reavaliar o citado termo em consonância com a realidade em que se situa o intérprete. Bem como salientou Miguel Reale ${ }^{17}$, "Feita a lei, ela não fica, com efeito, adstrita às suas fontes originárias, mas deve acompanhar as vicissitudes sociais. É indispensável estudar as fontes inspiradoras da emanação da lei para ver quais as intenções do legislador, mas também a fim de ajusta-la às situações supervenientes".

Da mesma forma posiciona-se Hermes Lima ${ }^{18}$, quando ao citar Ferrara, afirma que

17 REALE, Miguel. Lições Preliminares de Direito. Saraiva, 17ª ed., 1990, p. 278 .

18 Opus cit p. 153. 
[...] a ratio legis pode mudar com o tempo. O intérprete examinando uma norma de há um século não está incondicionalmente vinculado a procurar a razão que norteou o legislador de então, mas qual é o fundamento racional de agora. Assim, pode acontecer que uma norma ditada para certo fim adquira função e destino diverso. A ratio legis é uma forca vivente móvel que anima a disposição acompanhando-a em toda sua vida e desenvolvimento; é como a linfa que sempre mantém verde a planta da lei e faz brotar novas flores e novos frutos. A disposição pode, dessa maneira, ganhar com o tempo um sentido novo e aplicar-se a casos novos. Sobre este principio baseia-se a chamada interpretação evolutiva. A ratio legis, acentua Ferrara, é objetiva e atual, não podendo, portanto, ser confundida com a vontade do legislador.

Aliás, como bem salientaram Peces e Barba, qualquer direito deve ser interpretado de acordo com sua historicidade, na medida em que a mesma noção de Direito merece ser devidamente adaptada às mutações a que é submetido o Estado, na mesma proporção em que este, inexoravelmente, sofre as influências dos fatores reais de poder:

A relação da qual, hoje, nos ocupamos, é produzida entre o Direito moderno e o Estado moderno. (...) Neste primeiro problema que enfrentamos na indignação do conceito do Direito, já nos defrontamos com um elemento que perpassará por toda a reflexão jurídica, sua historicidade. Por se tratar de um produto cultural, a variante do tempo deverá, quase sempre, ser levada em conta ${ }^{19}$.

19 GREGORIO, Peces; BARBA, Martínez. Introducción a la Filosofia del Derecho, Madrid: Debate, 1983, p. 30 a 32: "La relación que hoy nos ocupa se produce entre el Derecho moderno y el Essado moderno (...) En este primer problema que afrontamos en la indagación del concepto del Derecho, nos encontramos ya con un elemento que será permanente en toda la reflexión jurídica, 
A utilização dessa exegese permitiria a punição do instigador literário, pois, conforme se advertiu, o sujeito passivo ver-se-ia, a cada dia, mais delimitado em face do avanço das técnicas de pesquisa mercadológica e da própria tecnologia, ambas propiciando um estreitamento do público alvo. Em prol dessa conclusão, a incriminação do colaborador ficaria na dependência do objeto da obra literária, a forma como foram expostas as opiniões do autor, os caracteres pessoais do público que se visou convencer etc. Ademais, não se deve perder de vista a necessidade de se realizar minuciosa análise dos elementos que compõem o crime, pois, conforme se frisou, o exercício da liberdade de expressão, por si só, não induz a caracterização da infração.

Faz-se alusão, por exemplo, a certos autores de páginas na internet que divulgam, gratuitamente, técnicas de autocídio. Ao propagarem este tipo de conduta, o fazem, geralmente, sob o pretexto da liberdade de expressão intelectual. Observa-se, no entanto, que vontade do falso pensador está cada vez mais próxima de grupos facilmente determinados pelo objeto de sua manifestação intelectual: tetraplégicos, portadores de doenças raríssimas, fanáticos religiosos etc. Reciclando o pensamento dominante que, por décadas, tem permanecido estático, torna-se fácil observar a semelhança que essas modernas apologias possuem com as antigas seitas de propagação do suicídio, tendo, por isso, responsabilizado seu líderes. Pode-se citar a seita "Templo do Povo", liderado por Jim Jones, responsável por levar a morte 912 pessoas; a seita do líder cego vietnamita Can Van Liem, tendo propagado a morte simultânea de 53 pessoas.

\section{Realizando a Vontade do Constituinte Originário.}

Em última análise, não poderíamos preterir discutir o assunto sob a ótica do constitucionalismo. Pleiteamos, neste momento, questionar sobre a efetiva realização da vontade do Titular do Poder Constituinte Originário, uma vez que o posicionamento pacífico da doutrina (e a nosso ver um tanto quanto acomodado) reflete a perfeita desproporção dos princípios jurídicos acolhidos na Carta Política. É de aceitação pacífica pela doutrina a idéia de que não há como se beneficiar uma liberdade individual preterindo, abusivamente, liberdades públicas alheias. Estão as liberdades constitucionais individuais, su historicidad. Al tratarse de un producto cultural la variable del tiempo debe, casi siempre ser tenida en cuenta". 
como insistem os renomados juristas, contaminadas de uma dimensão social. Com efeito, não podemos conceber a idéia de que a liberdade de expressão, seja qual for o conteúdo de seu exercício (artístico, científico, religioso etc.) possa ser utilizada com prejuízo das liberdades constitucionais alheias.

Não está em nosso propósito chamar a atenção apenas da tão preconizada restrição às liberdades individuais, embora essa tenha sido essencial à consagração do Estado Liberal. Indiscutível é o mérito do Liberalismo na formulação do conceito de restrição às liberdades públicas. Não obstante não se possa negar as limitações das prerrogativas fundamentais ${ }^{20}$, não se concebe um Estado Democrático apenas diante da existência dessas limitações. Embora tenham o liberais grande parcela de mérito na conquista das liberdades-impedimento, muitas, inclusive, responsáveis pela edificação de uma teoria de direitos subjetivos, tal realidade nem sempre esteve em harmonia com os preceitos de ordem democrática. Basta observar que nem todos os filósofos e pensadores do século XVIII eram, em absoluto, democráticos. Norberto Bobbio $^{21}$, em excelente trabalho sobre Teoria Política, ratifica essa opinião ao extrair o real conteúdo do termo "liberdade" perfilhada na obra de Kant. Ora, o referido autor alemão, considerado por muitos como um propagador dos ideais da democracia, não seria, segundo Bobbio, um pensador, em absoluto, democrático. A opção do jurista italiano estaria fundamentada nos dois sentidos que poderiam ser revelados a partir do conceito de "liberdade":

[...] a liberdade na qual se inspira a sua concepção de direito, Estado e de história, não é a liberdade democrática, mas a liberdade liberal. Essa conclusão tem também por objetivo confirmar, através da análise de um texto célebre, a existência e a coexistência das duas noções fundamentais de

20 ALEXY, Robert. Teoria de los derechos fundamentales. Madri: Centro de Estudos Constitucionales, 2001, p. 268. Melhor obra sobre o tema, o autor procura demonstrar, ao contrário do que pensa Fr. Klein, a existência de restrições aos próprios direitos fundamentais.

21 BOBBIO, Norberto. Teoria geral da política: a filosofia política e as lições dos clássicos. Rio de Janeiro: Ed. Campus. 2000, p. 113. Para maiores detalhes, vide a distinção feita pelo autor quando se refere aos dois tipos de liberdade de Kant: a primeira traduzida como autodeterminação individual; a segunda, como autodeterminação coletiva. 
liberdade, e de mostrar a necessidade de mantê-las bem distintas. De um lado, a obra de Kant é uma prova de validade daquela distinção; de outro, a distinção revela-se, no exame do pensamento de Kant, útil como critério de compreensão histórica e de avaliação crítica ${ }^{22}$.

A distinção entre a liberdade no Estado Liberal e a liberdade no Estado Democrático tem a anuência dos filósofos contemporâneos, propiciando, por conseguinte, sérias conseqüências de natureza jurídica. Com efeito, a mera restrição às liberdades públicas não conduz, integralmente, à realização do Estado Social. A simples restrição, v.g, ao exercício da propriedade não traduz, de per si, a tentativa de contextualizar esse direito em sua acepção social.

Buscam os falsos intelectuais, em face de um panorama tipicamente liberal, tão somente suprir os desalentos e as necessidades psicológicas de um mundo gasto e destituído de referências éticas e morais. A premente conjuntura social não consente outra saída para os inescrupulosos senão fomentar o abuso da ingenuidade humana diante de suas carências afetivas. Isso é facilmente denotado quando as influências sugestivas tendem por desmandar a principal e universal característica dos direitos fundamentais, qual seja, sua indisponibilidade. O Estado Liberal ultracapitalista, filiado a um regime democrático apenas aparente, cuida por gerar pactos contratuais que extrapolam a dignidade da pessoa humana. O pacta sunt servanda, agora mais intenso do que nunca nas sociedades políticas subdesenvolvidas, sobrepõe-se aos caracteres universais dos direitos fundamentais, até mesmo nos países que já obtiveram sua incorporação através da historicidade.

$\mathrm{Na}$ verdade, a instigação de atos antijurídicos sob o pretexto de uso de liberdade intelectual, senão constitui crime, torna-se prática ainda mais proibitiva quando instiga ou induz a renúncia a direitos indisponíveis. Não se pode conceber o exercício de uma prerrogativa constitucional quando hostil aos postulados democráticos e, principalmente, à vontade do constituinte originário. Extrai-se essa inferência de vários dispositivos da Carta Federal de 1988, os quais, direta ou indiretamente, alertam para o inafastável acatamento dos caracteres dos direitos fundamentais, a citar: “A União não intervirá nos Estados nem no Distrito Federal, exceto para: 
(...) assegurar a observância dos seguintes princípios constitucionais: (...) direitos da pessoa humana" (Art.34, VII, b); ou "Todos são iguais perante a lei, sem distinção de qualquer natureza, garantindo-se aos brasileiros e aos estrangeiros residentes no País a inviolabilidade do direito à vida, à liberdade, à igualdade, à segurança e à propriedade, nos termos seguintes: (...) ninguém será submetido à tortura nem a tratamento desumano ou degradante" (Art. $5^{\circ}$, caput c/c III); ou "a lei punirá qualquer discriminação atentatória dos direitos e liberdades fundamentais" (Art. 5\%, XLI).

Não se trata de perfilhar, conforme antes certificamos, teoria oposta a todo tipo de manifestação intelectual envolvendo, direta ou indiretamente, conteúdo apologético ao suicídio. Conforme foi exposto, o exercício da atividade científica ou artística encerra responsabilidades para com a vontade contextual do titular do poder constituinte. Tais deveres consistem, inicialmente, em restrição temporária do exercício dessas atividades após sua fruição, pois, conforme salientou Alexandre de Moraes:

A censura prévia significa o controle, o exame, a necessidade de permissão a que se submete, previamente e com caráter vinculativo, qualquer texto ou programa que pretende ser exibido ao público em geral. O caráter preventivo e vinculante são o traço marcante da censura prévia, sendo a restrição à livre manifestação de pensamento sua finalidade antidemocrática. ${ }^{23}$

Num segundo momento, abstraindo-se os ideais individualistas dos liberais burgueses, as atenções do Estado Democrático estariam voltadas a atitudes positivas do Poder Público em conferir contornos sociais ao exercício dessa prerrogativa. Manoel Gonçalves Ferreira Filho ratifica este pensamento, ao estampar críticas às declarações individualistas:

Essa evolução se inicia com a crítica logo feita pelos socializantes ou socialistas ao caráter "formal" das liberdades consagradas nos documentos individualistas. Essas liberdades seriam iguais para

23 MORAES, Alexandre de. Direito Constitucional. São Paulo: Atlas, $15^{\text {a }}$ ed., 2004, p. 81. 
todos, é certo; para a maioria, porém, seriam sem sentido porque a ela faltariam os meios de exercêlas. De que adianta a liberdade de imprensa para todos aqueles que não têm os meios para fundar, imprimir e distribuir um jornal? - perguntavam esses críticos. (...) Destarte, a atribuição em realidade para todos do direito de exercer esses direitos fundamentais implicaria uma reforma econômico-social, ou, ao menos, uma intervenção do Estado para que o mínimo fosse exercido ${ }^{24}$

\section{Conclusão}

Diante do exposto, arrogamos autoridade para concluir que, de modo precípuo, a norma penal incriminadora deverá, uma vez respeitando os preceitos gerais do direito penal, avocar o critério interpretativo que melhor corrobore com os caracteres essenciais dos direitos fundamentais. Atentese para o detalhe de que nem sempre tal preferência conduz a realização do interesse coletivo, ou melhor, da maioria. Mister torna-se, conforme muito bem dispôs Gustavo Binenbojm:

[...] embora consagrando a democracia e o princípio da soberania popular, as Constituições modernas dispõem sobre a forma a ser observada para a manifestação da vontade majoritária e sobre conteúdos mínimos que devem ser respeitados pelos órgãos representativos dessa vontade, sem, no entanto, suprimi-la. Assumindo a democracia como um jogo, a Constituição seria o manual de regras e, os jogadores, os agentes políticos representantes do povo. À Jurisdição constitucional, nesse contexto cumpre o papel de ser o árbitro do jogo democrático ${ }^{25}$.

24 FERREIRA FILHO, Manoel Gonçalves. Curso de Direito Constitucional. São Paulo: Saraiva, 22a ed., p. 249.

25 BINENBOJM, Gustavo. Tensões entre democracia e constitucionalismo: a legitimidade democrática da jurisdição constitucional. In: A Nova Jurisdição 
Eis aí a grande missão do Estado Democrático de Direito: manter o equilíbrio dos princípios constitucionais de forma a promover a coexistência entre a vontade da maioria, inserta no principio de soberania popular, e a realização dos princípios jurídicos gerais que tutelam os interesses das minorias. Estará, portanto, excluída de nosso pensamento, qualquer teoria que possa, a todo custo e de forma antidemocrática, subverter os interesses daqueles que se manifestam através de suas obras literárias.

Em prol de uma análise de conteúdo estritamente criminal, a preferência pelo critério ampliativo na interpretação do termo "alguém", previsto no art. 122, justificou-se pela tentativa de harmonização da citada regra ao conjunto normativo. Seguindo esta linha de julgamento, concluímos pela existência do dolo eventual contra vítimas em quantidade indeterminada; ou melhor, inviável sua estimação de um número de vítimas dentro de uma escala de limites mínimos e máximos. Em outra oportunidade, buscamos acolher critério que pudesse justificar a expectativa dos autores de trabalhos escritos no aviltamento de um número determinável de pessoas, o que seria facilmente aceito pela doutrina moderna, segundo palavras de Fernando de Almeida Pedroso (vide nota 15, p. 8). Naquele momento, perfilhamos o critério de interpretação evolutiva, porquanto permitiria adaptar a norma em questão às mudanças de comportamento influenciadas pela indústria da informação. Diante deste segundo critério, procuramos demonstrar que, a cada dia, novas técnicas surgem na tentativa de se delimitar o destinatário da informação.

Como se pode denotar, foram propostas, preliminarmente, idéias à luz dos postulados gerais do Direito Penal, norteando a construção de um posicionamento original. Todavia, algo mais convincente tratou de melhor inspirar nossas conclusões: a busca pela revelação da real vontade do legislador constituinte originário. Concluímos que, se não se pudesse a traduzir esta vontade inicial, antes de um estudo analítico da norma penal em questão, de forma a estabelecer, com razoabilidade, quais os valores, bens ou princípios constitucionais que devam preponderar diante do caso concreto, realizar-se- $\mathrm{i}$ apenas o desejo do legislador constituinte vigente a época de elaboração da norma infraconstitucional. Enfatiza-se, entretanto, que tal vontade não objetiva expurgar os postulados gerais do Direito Criminal, tampouco satisfazer a todo custo os desejos da maioria; ao contrário, sua missão destina-se à harmonização de ambos.

Constitucional. Rio de Janeiro: América Jurídica, 2002, p. 48. 
Em nosso próximo artigo, apresentaremos discussão sobre uma possível teoria de presunção de inimputabilidade da vítima, quando de sua instigação, auxílio ou induzimento ao suicídio. Essa permitiria, uma vez desfigurada a figura típica da participação em suicídio, a construção da idéia de que todo colaborador àquela conduta seja indiciado, inicialmente, por homicídio. Tal idéia partiria da necessidade de se reinterpretar a resistência do sujeito passivo diante da evolução médica na identificação das patologias que levam ao suicídio. Evidentemente que tal ilação conduziria, de antemão, o aviltamento de certos postulados gerais já consagrados, como, por exemplo, o do favor rei e o da presunção de inocência. Seguindo os mesmos critérios, utilizaremos, inicialmente, o critério evolutivo de interpretação. A posteriori, faremos profunda reflexão sobre limites de atuação dessa ferramenta diante das técnicas de harmonização entre a democracia e o constitucionalismo. Excluída estará, igualmente, qualquer idéia tecnicista de construção de fórmula perfeitamente amoldável a todos os casos concretos.

Todos os argumentos que até aqui utilizamos, acreditamos ter sido fruto de uma verdade sistematicamente apreendida, fornecendo, desse modo, contornos científicos a essa singela obra. Discordamos daqueles que pensam estarem nossas proposições voltadas à formação de uma teoria de imputação objetiva, uma vez que, de nossa parte, não haveria a tentativa de se incriminar a divulgação do pensamento sem a demonstração do dolo ou culpa. Como ao leitor não é infenso retirar seu próprio ajuste definitivo, nossa defesa remonta às nossas mesmas linhas.

\section{Referências Bibliográficas}

ALEXY, Robert. Teoria de los derechos fundamentales. Madri: Centro de Estudos Constitucionales, 2001.

BINENBOJM, Gustavo. Tensões entre democracia e constitucionalismo: a legitimidade democrática da jurisdição constitucional. In: A Nova Jurisdição Constitucional. Rio de Janeiro: América Jurídica, 2002.

BOBBIO, Norberto. Teoria geral da política: a filosofia política e as lições dos clássicos. Rio de Janeiro: Ed. Campus. 2000.

CAPPELLETTI, Mauro; GARTH, Bryant. Acesso à justiça. Trad. de Ellen Gracie Northfleet. Porto Alegre: Fabris, 1988. 
FERREIRA FILHO, Manoel Gonçalves. Curso de Direito Constitucional. 22 ed. São Paulo: Saraiva, [s.d]

GREGORIO, Peces; BARBA, Martínez. Introducción a la Filosofia del Derecho. Madrid: Debate, 1983,

LIMA, Hermes. Introdução à Ciência do Direito. 23 ed. [s.1] Freitas Bastos, 1973.

MIRABETE, Júlio Frabini. Manual de Direito Penal. São Paulo: Atlas, 1991. Vol. 2.

MORAES, Alexandre de. Direito Constitucional. 15 ed. São Paulo: Atlas, 2004.

NOGUEIRA, Paulo Lúcio. Dos Crimes Contra a Vida. São Paulo: Saraiva, 1995.

PEDROSO, Fernando de Almeida. Dos Crimes Contra a Vida. [s.1]: Aide, 1996.

PÉREZ-LUÑO, Antônie Enrique. Los derechos humanos, significación, essatuto jurídico y sistema. Universidad de Sevilla, 1979.

REALE, Miguel. Lições Preliminares de Direito. 17 ed. São Paulo: Saraiva, 1990.

SILVA, José Afonso da, Curso de Direito Constitucional Positivo. 22 ed. São Paulo, Malheiros Editores, 2002. 